\title{
13 Marginalising the upper house
}

\author{
The Liberal Party, the Senate and \\ democratic reform in 1920s Canada
}

\author{
Adam Coombs
}

\section{Introduction}

Canadian voters in the 1921 Federal Election produced one of the most unexpected Parliaments in Canadian history. The incumbent Conservative Party, which had governed for the past ten years and seen Canada through the First World War, was now the third party in the House of Commons, and a combination of electoral defeats and retirements left it bereft of almost all of their senior leadership. As a final insult to the party, its new leader, Arthur Meighen, even lost his riding in Portage-Le-Prairie, Manitoba, to the newly formed Progressive Party. It was this Progressive Party, a collection of rural parliamentarians united under the informal leadership of Thomas Crerar, a former minister in the Conservative's wartime government, which was now the second largest party in lower chamber. The Progressives' rapid rise had only begun two years earlier when a group of angry farmers ran a candidate in an Ontario by-election to protest the Conservative's support for high tariffs on imported goods. Now this grassroots movement was the official opposition.

Most surprising of all was that the Liberal Party, now led by William Lyon Mackenzie King, had secured the majority of seats in the Commons. Having refused to support conscription in 1917, the Liberal caucus was reduced to a rump of Quebec members led by former prime minister Sir Wilfrid Laurier. By 1919 Laurier had died and King, a unilingual Anglophone who had spent the war working with the Rockefeller family in the USA, was elected leader of the Francophone-dominated party. Yet public anger at the Conservatives' failure to effectively manage the peacetime economy combined with the Progressives' surge in Western Canada handed the Liberals a one-seat majority on election night 1921.

In spite of his party's victory and the shambolic state of the Conservative Party, the new prime minister still faced substantial obstacles to implementing his legislative agenda. With only a one-seat majority in the House of Commons, the Liberal government was forced to temper their legislative ambitions. Additionally, the Liberals faced a hostile Senate dominated by Conservative partisans appointed by Prime Ministers Borden and Meighen during their decade in office. In order to meet this challenge, the Liberals needed to justify the supremacy of the House of Commons as the preeminent chamber of Parliament and thereby 
delegitimise any attempt by the Senate to invoke its constitutional power to delay, block or amend legislation. It is this process and its long-term consequences that will serve as the focus of this chapter. Specifically, it will argue that, between 1921 and 1930, the King-led Liberals drew on the concept of the democratic mandate or the idea that the governing party and its leader were chosen to speak for the Canadian people, in order to bolster their own political standing and limit the ability of the appointed Senate to hinder the Liberal government.

This particular case study demonstrates how governing parties in Westminster systems employed democratic concepts, such as the democratic mandate as a means of solidifying their own position while limiting any opposition from the upper chamber. Particularly in countries like Canada, where constitutional reform was not politically feasible, the possibility of structural reform to the Senate was nil. Hence, a government facing a hostile Senate in this constitutional context had to ensure that voters viewed any exercise of power by senators, however legally valid, as a violation of democratic norms. However, the long-term effect of such a strategy was to further undermine the legitimacy of the Senate in the eyes of the voting public. In Canada's case, for an institution that had faced questions of legitimacy since its creation in 1867 , these attacks could be particularly successful.

In order to demonstrate this argument, the chapter draws on two types of sources. The first consists of public remarks of key Liberal politicians, particularly those of Prime Minister King. The second is articles and editorials from prominent liberal newspapers of the era, such as the Manitoba Free Press (after 1931 the Winnipeg Free Press) and the Toronto Globe (later the Globe and Mail). Unlike earlier in Canadian history, when papers like the Globe were owned by political party leaders, they were independent operations with editorial policies controlled by their owners/operators, not the Liberals or the Conservatives. However, these newspapers still maintained strong connections to political parties, and their owners and editors were often involved in the affairs of the party. The most prominent example was the Winnipeg Free Press, which was owned by former Liberal cabinet minister Clifford Sifton and run by overtly partisan editor J. W. Dafoe. These papers thus provide a window into broader Liberal attitudes towards the Canadian Senate during the 1920s.

\section{Historical and political context}

Liberal Prime Minister William Lyon Mackenzie King's (1874-1950) personal history was unique for politicians of his era. While most Canadian politicians during the country's first fifty years were either born in the British Isles or heavily influenced by its history and politics, King was much closer culturally to Canada's southern neighbour, the United States of America.

King was the son of John King, an unsuccessful lawyer, and Isabella Grace Mackenzie, the daughter of William Lyon Mackenzie, a noted reform politician in early-nineteenth-century British North America and one of the leaders of the Upper Canada Rebellion of 1837 who spent time in exile in the United States. King spent his early life in Berlin, Ontario (now Kitchener), and completed his 
BA at the University of Toronto before studying law at Toronto's Osgoode Hall. King's formative educational experiences, however, were in the United States. After failing to get a professorship at Osgoode Hall, King studied at the University of Chicago, where he worked closely with American reformer Jane Addams. He subsequently received his MA in political economy and his $\mathrm{PhD}$ from Harvard University in Cambridge, Massachusetts. King returned to Canada in 1900 to work as a civil servant and in 1908 was convinced to run for the Liberal Party in a federal by-election. Upon winning a seat in Parliament, King was made minister of labour by Liberal leader Wilfrid Laurier. Yet King, like most Liberal ministers, lost his seat in the federal election of 1911 and subsequently returned to the United States, where he was hired by John D. Rockefeller Jr. to head the Rockefeller Foundation's Department of Industrial Research. King served in this role throughout most of the First World War, only returning to Canada in mid-1917 to run unsuccessfully for the Liberals in the 1917 federal election.

Two years later, in 1919, Wilfrid Laurier, longtime Liberal Leader and King's political mentor, died, precipitating the first leadership convention in Canadian history. King ran for the leadership and won on the fourth ballot. Ironically, King, a unilingual Anglophone, won thanks to the support of Quebec delegates marshaled for King by his Quebec-lieutenant and later attorney general, Ernest Lapointe. King thus led the Liberal Party into the 1921 federal election, the first after the return to peacetime after the upheaval of the First World War.

King's invocation of the democratic mandate during the 1921 campaign was one example as to how his time in the United States shaped his politics. King's specific interpretation of the democratic mandate as conferring power on the executive was an invention that traced its origins to the nineteenth-century United States and the rhetoric of American president Andrew Jackson (1829-1837).

Within parliamentary systems, a majoritarian interpretation of political power has always emphasised the presidential-like role of the prime minister and sought to reduce Parliament to simply a ratifying body. However, the idea that the people directly conferred power on a specific individual was an American reinterpretation of this idea (Ihalainen, Ilie \& Palonen 2016). This theory of mandate politics as it relates to elections rests on three basic assumptions. The first is the idea that election results carry a clear and directive message from the people to political leaders about their policy proposals. The second assumption is that this message is authoritative, and political leaders are duty-bound to uphold it. The final assumption is a negative imperative, stating that political leaders should not, barring exceptional circumstances, take substantial action without the expressed approval of the people in the form of a mandate granted through an election (Kelley Jr. 1983). Essentially, the idea of a mandate can be summarised as follows: voters send a message with their votes and public officials receive this message and act on it (Grossback, Peterson \& Stimson 2006).

Andrew Jackson was the first to interpret majoritarian ideas through the lens of executive action: he argued that the president embodied the will of the American people and that his election was a mandate in favour of his key policies (Dahl 1990). Yet Jackson's views were not widely accepted by subsequent nineteenth-century 
presidents, as the majority continued to argue for legislative or parliamentary, rather than executive, superiority. In 1912 Woodrow Wilson's electoral victory marked the reintroduction of mandate politics to American democracy. Rather than accepting the argument that legislative superiority was imperative for true democracy, Wilson reversed the proposition, arguing that legislative restrictions on presidential power were undemocratic. For Wilson, as for Jackson before him, the president was the only truly elected representative of the American people and had a popular mandate to act, while congressmen spoke only on behalf of specific regional interests (Dahl 1990).

As this chapter will demonstrate, Mackenzie King adopted this idea of the democratic mandate to reinforce his position as prime minister. The major challenge for King and his party in adopting this strategy was that, unlike in a proportional representative system and to a lesser degree the American system, in the Westminster system, there was no direct link between the popular vote and what party forms government. Rather, King was forced to construct what Matthew Shugart and John Carey describe as a 'false mandate' (Shugart \& Carey 1992). These circumstances meant that it was much more challenging for King to convince Canadians that such a concept was relevant to Canadian politics. Ultimately, though, King and the Liberals were able to take a concept developed in the United States and successfully employ it in a Canadian context.

While King's invocation of the democratic mandate was new, as the Ottawa Evening Citizen highlighted in their 1921 election day issue, debating how the Senate and House of Commons related to each other was not. It had been the subject of political discussion in Canada since even before the Confederation in 1867. The newspaper chronicled eight previous attempts by the Commons to pass legislation limiting the power of the Senate, all of which failed (Ottawa Evening Citizen 1921). Additionally, as Norman Rogers informed King in a 1927 report, the Conservative MP Edward Lancaster had introduced legislation in the lower house calling for the complete abolition of the Senate in 1909, 1910 and 1911 (Rogers 1927). Finally, the Liberal Party's grassroots had repeatedly voiced their opposition to the power of the appointed Senate. Particularly during the 1919 party convention, numerous local Liberal organisations had forwarded resolutions supporting a variety of legislative proposals relating to the Senate, with options ranging from a mandatory retirement age to outright abolition. The predominant argument used to justify their resolutions was that, as the Northern Ontario Liberal Association detailed, the Senate was 'an appointed body, holding office for life, which is contrary to Liberal opinion and principle' (National Liberal Convention 1919). Thus, King's attacks on the power of the Senate not only were timely but also reflected a history of Liberal support for Senate reform initiatives and tapped into existing sympathies among many of the party's grassroots.

\section{The English example}

When discussing the role of the upper chamber of Parliament, the Liberals not only drew on Canadian history, but also on the debate over the powers of the 
House of Lords in Britain. Particularly, in the years leading up to the First World War, clashes over what legislative or procedural mechanisms were required to resolve deadlock between the Commons and Lords became one of the most controversial issues in early-twentieth-century British politics. Traditionally, the only mechanism for resolving a deadlock between the Commons and the Lords was for the Crown to appoint additional Lords supportive of the particular piece of legislation. With the passage of the Reform Act 1832, only after King William IV threatened the Lords with creating an additional eighty peerages to ensure the bill passed, the convention developed that the Lords would not defeat publicly popular legislation. Additionally, convention dictated that the House of Lords could not amend money bills, as only the Commons had the ability to decide what funds would be available for the Crown to spend. Although unable to amend money bills, the Lords still had the prerogative to defeat them outright, setting the stage for the 1909-1911 conflict over the People's Budget (Bradley \& Ewing 2008).

By the turn of the twentieth century, the Conservative-Unionists had a substantial majority in the Lords. Despite their dominance in the upper house, the 1906 general election saw the election of a reform-minded Liberal administration which had publicly committed to substantial public welfare programs. Between 1906 and 1908, conflict simmered between the two chambers, with the Lords rejecting or modifying key pieces of Liberal legislation. The conflict came to a head in 1909 when Chancellor of the Exchequer David Lloyd George introduced 'The People's Budget', which, among other measures, increased income taxes on the wealthy and instituted an additional land tax targeting the gentry. Conservatives in both houses saw the budget as highly redistributive and an attack on the aristocracy. While the Conservatives did not have the votes to defeat the budget in the Commons, they did in the House of Lords and voted 350 to seventy-five to veto the budget (Ball \& Seldon 1994).

In response, the Liberals derided the upper chamber as undemocratic and called for a reform of the House of Lords. Additionally, Prime Minister Herbert Henry Asquith asked King Edward VII to appoint enough Liberal peers to ensure the budget's passage. However, that would require appointing over three hundred new peers, and the King refused to take such drastic action without the clear support of the British electorate. Consequently, Asquith asked for Parliament to be dissolved, and in the General Election of January 1910, the Liberals retained power, albeit with the help of Labour and Irish Parliamentary Party support in the Commons. This coalition was subsequently able to force through a modified version of the 1909 budget but with the controversial land tax removed. Inspired by the budget crisis, Asquith attempted to use his parliamentary majority to pass legislation removing the House of Lords' veto over legislation and replace it with the ability to delay money bills for one month and all other bills for a maximum of two years. This measure was, as predicted, quickly defeated in the upper chamber. Yet with the death of Edward VII in May of 1910 and George V's ascension to the throne, Asquith now had a sympathetic monarch willing to appoint additional peers to ensure the passage of reform legislation. When the Liberals' reform legislation was once again defeated in the House of Lords, Asquith requested another 
general election for December 1910, which his coalition subsequently won. The Liberals were now able to pass a reform bill similar to the one rejected in 1910, and in August of 1911 the House of Lords passed the Parliament Act 1911 by a seventeen-vote margin. The political drama surrounding the House of Lords reforms was well covered in the Canadian press, and many Canadians believed that Asquith's reforms should serve as inspiration for King and the Liberals.

The main problem was that the Parliament Act 1911 did not address the main obstacle to the Liberal Party of Canada's legislative agenda. One of the key constitutional justifications for legally defining the powers of the Lords in respect to the Commons was to ensure that the Lords could not dictate government spending by amending or defeating a budget. On other legislation the Lords could delay a bill by two years. It was thus possible to understand the 1911 reforms not as a radical redistribution of powers within Parliament but rather a codification of existing convention. Within the Canadian context, however, the issue was not money bills, as King's budgets easily passed the Senate, but rather criminal code reform. In particular, since their convention in 1919, the Liberals had pledged to repeal the wartime anti-subversion provisions in Section 98 of the Criminal Code of Canada. Since the end of the First World War these laws had been used by police to target left-wing organisations, and repealing the section was almost unanimously opposed by Conservative senators. In order to ensure that his government's legislation passed unimpeded, any Senate reform bill would have to sanction much more extensive changes than the 1911 British one. Hence, the Liberals had to justify any future proposal not by appealing to constitutional precedent, as the British Liberals did, but by creating their own standards of democratic legitimacy based on the supposed desires of the Canadian people.

\section{Attacks on the legitimacy of the Senate}

Despite the centrality of the Senate in Liberal Party discourses and a legislative template based off the British Parliamentary Act 1911, Prime Minister King did not publicly discuss the need for such a bill until the summer of 1924, three years after being sworn in as prime minister (Manitoba Free Press 1924a). Rather, for the first three years of their term the Liberals relied on the Manitoba Free Press and their partisan Liberal editor J. W. Dafoe to build support for legislation limiting the Senate's power by highlighting how the Senate abused its power to 'trip up the government'. When King finally did address the issue in July 1924, he told the House, 'This year we have instances of bills that have passed this House in three separate sessions of parliament, and which have been rejected each time by the second Chamber'. King then referred to the 1911 British bill and argued,

The time has come when the Commons in Canada should seek to gain rights and privileges with respect to legislation originating in the Chamber similar to those which have been obtained by the House of Commons in the Parliament of Westminster. 


\section{Adam Coombs}

After assuring the House that his government would introduce legislation to ensure the supremacy of the House of Commons in the near future, King proceeded to justify his proposal by invoking a sense of civic duty in his audience. King told the House, 'I think we owe it to the people of our country with respect to laws demanded by the electorate to see to the supremacy in parliament of the elective chamber' (King 1924b). King claimed the electorate had chosen the Liberals to govern on the basis of their proposed laws, so the Senate had no moral authority to subvert the desires of not only cabinet but also the people they claimed to represent.

This message, that the Liberals' attempts to limit the power of the Senate were part of the fight to protect the rights of the people, was a key theme in many of the Prime Minister's speeches throughout the summer of 1924. In one from 20 August 1924 to the Kent County Liberal Association in Chatham, Ontario, King assured his audience, 'The government would proceed with all due caution in an effort to secure supremacy of the people's will'. While downplaying the radical natures of his party's proposals, King stated,

I do believe the people will expect a Liberal government to see that the machinery of government is so arranged as to make possible that the will of the people will prevail in those great measures which are of such great concern to the people as a whole.

(King 1924a)

For King it was obvious that the House of Commons should be preeminent, and any limits imposed on it by an appointed Senate were necessarily anti-democratic. Much like his comments in the Commons in July, King asserted that the Liberals, by virtue of their position as the governing party, were duty-bound to implement the wishes of the people expressed through a general election. Any partisan advantage the Liberals gained from this legislation was simply a by-product of the party's resolute commitment to democratic governance.

Despite spending the summer rallying support for his cause, King and the Liberals lacked sufficient confidence in their one-seat majority to introduce legislation on the matter during the fall session of 1924. Rather, King made vague promises to pass a bill similar to the 1911 British one without actually committing to anything. Such hesitancy did not stop the Manitoba Free Press from outlining potential legislation in a most generous light. In an editorial from October of 1924 Dafoe argued, 'The object of a second chamber is to ensure careful deliberation and to prevent hasty, ill-considered legislation. The proposed amendment would allow for this without permanently blocking the will of the people'. Additionally, Dafoe attempted to undermine any opposition to reform, stating,

Opposition to such an amendment cannot come from regard for the public interest but only from dark, ulterior considerations. Is the will of the people to prevail in Canada, or are the interests to retain the hold which they have had upon the government of the country through the irresponsible Senate and otherwise? 
By invoking the idea that the Senate was not responsible to any elected body, Dafoe sought to stigmatise any exercise of the Senate's constitutional power to block legislation. In the pages of the Free Press, what could be interpreted as a simple partisan conflict between Liberals and Conservatives was instead presented as a clash between the democratically elected representatives of the Canadian people and nefarious forces acting out of self-interest.

In December of 1924 The Manitoba Free Press published another editorial attacking Conservatives who defended the status quo with regard to the Senate. The paper characterised the Tory intransigence as misguided, stating, 'The Second Chamber occupies no such invincible position as our die-hards and stand-patters think' (Manitoba Free Press 1924b). In the face of substantial and sustained opposition from Conservative parliamentarians, the Free Press became more vocal in their support of the Liberal position. In an article from the summer of 1925 titled 'The Senate Reaches Out', the paper informed readers that not only were Senators and their Conservative allies in the House of Commons resisting reform but they also were the driving force behind

a persistent movement to enlarge the powers of the Canadian Senate for a reason that is quite plain. Powers and influences that believe they have an indefeasible right to control this country are turning to the Senate as the grip upon the Commons shows signs of weakening.

Much as they had during the 1921 election campaign, the Liberals and their supporters sought to continue this attack on the Conservatives for failing to respect the basic pillar of Canadian democracy: responsible - or cabinet - government. As Dafoe reminded readers, 'our nominated Senate is . . . entirely irresponsible' (Manitoba Free Press 1925). But just as the Conservative or Union Government had had every constitutional right to govern until the House was dissolved, for they commanded a majority in the Commons, the Senate had a legal right to amend or veto legislation, and doing so did not contravene the tenants of responsible government. However, rather than relying on constitutional arguments which served only to undermine the Liberals' position, the party's intellectual leaders drew on the rhetoric of popular democracy to argue for an entirely new constitutional convention.

The Manitoba Free Press was not alone in supporting the Liberals. On 22 December 1924, the same date as that of the Free Press editorial quoted earlier, the traditionally Liberal Toronto Globe published a long editorial arguing in favour of legislation limiting the Senate's power. Specifically relying on Western Canadian grievances to bolster its contention, the Globe piece presented the Canadian Senate as a unique institution in democratic countries, stating,

In no other country with a parliamentary tradition is the Upper House so frankly based on party patronage and so wholly independent of public opinion or public favour. Students of constitutional history who believe in democracy have a logical quarrel with such a body. 
The paper declined to offer any evidence for its assertion, demonstrating how alleging that the Senate was uniquely undemocratic had simply become part of the arsenal of arguments Liberal supporters deployed with regularity. In the Free Press editorial from June of 1925, Dafoe compared the Senate unfavorably with the British House of Lords, writing, 'The House of Lords, it appears, is a mere shadow of a legislative body compared with our nominated Senate' (Manitoba Free Press 1925). Dafoe chose to ignore the hereditary nature of the House of Lords or the presence of Church of England bishops in the British upper house, rather emphasising that the appointed nature of the Senate combined with its unrestricted power to amend or veto legislation should be the primary factor in determining the democratic nature of each country's parliament.

\section{Legislative inaction}

Despite the advocacy of Liberal newspapers, legislation similar to the British initiative faced substantial obstacles. First was that it would require approval from both the House of Commons and the Senate. Essentially, the Conservativedominated Senate would have to acquiesce to the supremacy of the Liberalcontrolled Commons. Furthermore, the Senate had a constitutionally mandated number of seats, so the Prime Minister could not convince the governor general to appointing additional senators to ensure the government's legislation passed. Such a political reality meant that any reform initiative was a long-term project for the Liberals. As a result, King was willing to use the possibility of Senate reform as a tool for ensuring the Progressive Party supported the Liberals' tenuous majority. To do so, King made a series of personal guarantees to the Progressive Party regarding Senate appointments, pledging to appoint only Senators who would agree to support unspecified reform measures in the future. Thus, once the Liberals gained a majority in the Senate, they would then be in a position to pass whatever legislation deemed necessary. This solution to the challenge posed by the Senate was deeply flawed, as neither King's assurances nor the pledge of newly appointed Senators was legally enforceable. Even if the Progressives withdrew their support for the Liberals in the House of Commons to punish King's perfidy, once a Senator was appointed, there was no way to ensure they honoured the pledge King had extracted from them. As a consequence the Progressive Party dismissed this overture from the Liberal Party (Fraser 1954).

With the Liberals frustrated in the Commons, King's attempts to equate opposing the Liberal government's policies with opposition to democratic governance generally became an important campaign message for the Liberal Party in the September 1925 federal election. In a campaign pamphlet titled "Progress and Achievement", the National Liberal Federation employed King's rhetoric to appeal directly to voters. The pamphlet first reiterated the problems the Liberal administration faced from a hostile Senate before demonstrating how they would solve this problem:

When there is a change in Government in Canada it usually happens that the Senate is controlled by the Opposition. This embarrasses a new government 
and its majority in the House and prevents the will of the people being fully carried out as expressed at the general election. . . . The people believe that the Canadian House of Commons should have the same power as the British House of Commons to pass legislation and the Prime Minister personally declared this to be his view. How he is going to bring this about was fully set forth in his keynote speech in North York. Liberal Senators already in office, as well as those who are to be appointed, will be pledged to support the necessary constitutional change. The government in this campaign is seeking a mandate from the people. If that be forthcoming, the will of the people will be translated into political action as soon as the supporters of the government constitute a substantial majority of the senate.

(Liberal Party of Canada 1925)

What was essentially King's promise to the Progressives earlier in 1925 was now elevated by the National Liberal Federation to a key election pledge. The author echoed King's public comments by emphasising how critical it was that the Commons and through it the cabinet have unimpeded power to pass legislation. The Liberals justified this position by appealing to the idea of a democratic mandate conferred through a general election. Specifically, the Liberals argued that the victorious party in an election represented the will of the Canadian people. Such a claim was a fabrication though, as only 41 per cent of voters supported the Liberals in the 1921 election. Furthermore, with only 67.7 per cent voter turnout, only 29 per cent of eligible Canadians actually voted for the Liberals. For King to claim that the 1921 election results meant the Liberal Party spoke on behalf of all Canadians was a rhetorical sleight of hand designed to delegitimise opposition to the Liberal legislative agenda.

King's ability to claim a mandate from the people was further undermined after the 1925 federal election. The Liberals lost the popular vote 46 per cent to 40 per cent to the Conservatives and also won fifteen fewer seats, taking one hundred to the Conservatives 115 . Yet King refused to resign as prime minister and, with the support of the twenty-two Progressive Party members, continued to govern. King's ministry managed to hold power until June 1926, when a scandal over bribery in the Department of Customs and Excise brought down the government. Before his government was defeated on a motion of censure, King requested the governor general dissolve Parliament and call a general election, but his request was refused. Instead, the governor general offered Arthur Meighen a chance to govern. Meighen's ministry lasted only three days before being defeated in the House of Commons, forcing a general election. Ultimately, though, the federal election of 1926 was only a partial victory for the Liberals. While they managed to win a plurality of seats with 116 and increase their share of the popular vote by 3 per cent (to 43 per cent), the Liberals lost the popular vote by 2 per cent to the Conservatives and were still seven seats short of a majority. However, King was able to rely on the eight votes of the Liberal-Progressives who, led by Manitoba MP and former Progressive Party leader Robert Forke, agreed to caucus with the Liberals and support the government on matters of confidence. Thus, much like after 1921, the Conservatives were once again facing a majority government in 
the House of Commons and had to rely on their presence in the Senate to obstruct King's legislative agenda.

Without the political imperative of securing Progressive Party support on a vote by vote basis and with an increasing number of Liberal appointees in the upper chamber, curbing the power of the Senate was a much less pressing issue for King. Rather than risk engaging in public debates regarding the Senate, King commissioned a private report for the cabinet on political options regarding the upper chamber. King's personal secretary and future Liberal Member of Parliament Norman McLeod Rogers was tasked with writing this report and presented his recommendations to the Liberal Cabinet on 12 September 1927. In his report Rogers engaged with the idea of how the Senate limited the power of the elected House of Commons. Rogers recognised that, 'An elective Senate having a direct mandate from the people would be more aggressive and active in the discharge of its functions, and would thus command a greater respect throughout the country'. However, he then went on to clearly articulate the Liberal Party's reasons for opposing an elected upper chamber, stating:

If the Senate were elective, would it not be disposed to claim equal powers with the House of Commons, or at least to insist on a measure of control with respect to money bills? Moreover, an elected Senate would be an avowedly partisan body. If the majorities in the two houses were of the same political complexion, the Senate would impose no effective check on the House of Commons. If the majorities in the two houses were of opposite political complexions, the Senate under partisan influence might abuse its powers for political purposes.

(Rogers 1927)

This report, produced by King's political ally, provided the necessary justification for the prime minister's approach towards the Senate. Rather than focusing legislative efforts on changing how the Senate was constituted, for as Rogers argued, no method would resolve the problem of partisanship in the upper chamber, the Liberals instead chose to focus on limiting the powers of the Senate. This approach still preserved the ability of the governing party to use Senate appointments for patronage purposes but also confirmed the power of the prime minister and his cabinet to ensure that the Senate would not have the democratic legitimacy to challenge the legislative power of King and his ministers.

From 1926 through the end of King's term in 1930, the Senate continued to delay controversial aspects of the Liberals' legislative agenda. Most notable was the government's continued attempts to repeal Section 98 of the Criminal Code, which the Senate defeated five times between 1926 and 1930. As well, the Senate defeated proposed changes to the Immigration Act in 1927. Yet these defeats presented an excellent opportunity for the Liberals to highlight their supposed superiority. In January 1928, Vancouver Sun editor and partisan Liberal Robert J. Cromie published an editorial condemning the Conservative Party, arguing that its willingness to obstruct legislation in the Senate was undemocratic. An exchange 
of letters between Cromie and Minister of Justice Ernest Lapointe demonstrated how the Liberals were happy to exploit the Conservatives' intransigence. Cromie told Lapointe, 'If the Liberal Party can hang this [anti-democratic] angle onto Toryism and drive it home . . it will be a master stroke'. Cromie then went on to offer a historical analogy:

From 1890 to 1900 there was an inferiority complex about the Conservative party in England because of their associations with the rich and rotting House of Lords; there was a superiority complex associated with Liberals during that period because they had associated with them the idea of progressiveness and intellectualism. That superiority complex is offering and is available to either of the political parties in Canada today; it properly belongs to the Liberal Party with its Liberal program of Canadianism.

(Cromie 1928)

The Senate certainly did obstruct Liberal legislation, but their opposition allowed the governing party to reinforce to voters that the Liberals were the true protectors of Canadian democracy. The Liberals were also willing to further enhance this impression by letting the Senate Conservatives defeat legislation in the upper chamber by ensuring enough Liberal Senators missed key votes (Government of Canada 1936). In the short-term, these defeats were a slight setback to that session's agenda but cumulatively they reinforced the image the Liberal Party wanted to present to the Canadian public. The fact that, after the 1930 federal election, the now governing Conservatives refused to take any action to address the Senate or to reform its practices also reinforced the Liberals' narrative. Ultimately, telling people that a certain party was anti-democratic was a much more effective when they occasionally acted in the exact manner that the Liberals warned they would.

\section{Conclusion}

Returning to power in 1921 after a decade in opposition was always going to present a number of challenges for the Liberal Party of Canada. Besides managing a razor thin majority in the House of Commons, the Senate of Canada was the largest obstacle to the Liberals' and Prime Minister King's ambitions. The challenge for the Liberals was how to sideline the Senate and make senators hesitant to use their constitutionally prescribed powers to delay, block or amend legislation. Barring that, how could the Liberals ensure that any short-term defeat in the Senate was turned into the Liberals' long-term advantage? As this chapter has argued, the approach King, his party and their allies in the media adopted was to invoke the concept of a democratic mandate, supposedly conferred on the Liberals by the Canadian people. That is, the Liberals claimed that they, as the ruling party, and King, as their leader, spoke and legislated on behalf of the Canadian people as a whole. Consequently, the Senate represented only the parochial and selfish interests of Conservative elites. 
Positing the existence of a democratic mandate, much less claiming that the Liberal Party had been granted one, required importing an American concept into a Canadian political system deeply influenced by its British connection and history. The Liberals and King exploited the lack of a consultative mechanism in the Westminster system through which the governing party could be clearly granted a mandate, allowing the Liberals to be vague in asserting how exactly they had been empowered to speak for the people. While Senators could point to the British North America Act 1867 and conventions in the Westminster system as the source of their powers, these claims could be undercut by appealing to broader principles and malleable concepts, which were used by the Liberals to delegitimise any attempt by the Senate to assert its authority. Ultimately, as demonstrated, Senators were still willing to use their power to defeat government legislation and did so with semi-regularity throughout the 1920s. But each defeat also further enhanced the Liberals' narrative of a democratic party protecting the people and their freedom to govern themselves. By using its constitutionally granted powers, the Senate did not effectively assert itself but rather contributed to its ongoing irrelevance by confirming the worst allegations of King and the Liberal Party.

\section{References}

Ball, S. and Seldon, A. (eds.) (1994), Conservative Century: The Conservative Party since 1900 (Oxford: Oxford University Press).

Bradley, A.W. and Ewing, K.W. (2008), Constitutional and Administrative Law [8th edition] (Harlow: Longman).

Cromie, R.J. (1928), Correspondence from Robert J Cromie to Ernest Lapointe, 10 January, Vol.3, File 3, Ernest Lapointe Fonds, Library and Archives Canada, Ottawa, Ontario, Canada.

Dafoe, J.W. (1924), 'The senate and the veto', Manitoba Free Press, 22 October.

Dahl, R. (1990), 'Myth of the presidential mandate', Political Science Quarterly 105(3), pp. 355-372.

Elections Canada (2019), 'Voter turnout at federal elections and referendums'. Available at: $\quad$ www.elections.ca/content.aspx ?section $=$ ele\&dir $=$ turn\&document $=\mathrm{index} \& l$ lang $=\mathrm{e}$ (accessed 13 March 2019).

Fraser, B. (1954), 'A new senate, this is why we need it', Maclean's, 15 April, p. 40.

Grossback, L., Peterson, D. and Stimson, J. (2006), Mandate Politics (New York: Cambridge University Press).

Government of Canada (1936), 'Section 98 of criminal code' 20 June 1936, Box 11, File 38, Grant Dexter Fonds, Queen's University Archives, Kingston, Ontario, Canada.

Ihalainen, P., Ilie, C. and Palonen, K. (2016), 'Parliament as a conceptual nexus', in: Ihalainen, P., Ilie, C. and Palonen, K. (eds.), Parliament and Parliamentarism: A Comparative History of a European Concept (New York-Oxford: Berghahn books), pp. 1-16.

Kelley Jr., S. (1983), Interpreting Elections (Princeton, NJ: Princeton University Press).

King, M. (1924a), 'Speech by Mackenzie king to Kent liberal association in Chatham', 20 August. Vol. 630, Senate Reform, R.B. Bennett Fonds, Library and Archives Canada, Ottawa, Ontario, Canada.

King, M. (1924b), 'Transcript of a speech by Mackenzie king in the house of commons', 19 July, Vol. 630, Senate Reform, p. 389339, R.B. Bennett Fonds, Library and Archives Canada, Ottawa, Ontario, Canada. 
Liberal Party of Canada (1925), Progress and Achievement, Publication \#1, September 1925, Vol. 1200, Liberal Political Pamphlets, Liberal Party of Canada Fonds, Library and Archives of Canada, Ottawa, Ontario, Canada.

Manitoba Free Press (1924a), 'The branch lines that were not built', 9 January.

Manitoba Free Press (1924b), 'The senate and its powers', 22 December.

Manitoba Free Press (1925), 'The senate reaches out', 26 June.

National Liberal Convention (1919), Resolutions, Recommendations and Suggestions for Platform and Programme, 5-7 August, Vol. 1215, general election - 1940 pamphlets and speeches, liberal party of Canada fonds, Library and Archives Canada, Ottawa, Ontario, Canada.

Ottawa Evening Citizen (1921), 'Eighth attempt to curb power upper chamber', 6 December.

Rogers, N.M. (1927), The Reform of the Senate, 12 September 1927, MG26-J2, Vol. 1052 Microfilm reel C2723, pp. 97087-97152, William Lyon Mackenzie King Fonds, Library and Archives Canada, Ottawa, Ontario, Canada.

Shugart, M. and Carey, J. (1992), Presidents and Assemblies. Constitutional Design and Electoral Dynamics (Cambridge: Cambridge University Press).

The National Archive (1911), Parliament Act 1911. Available at: www.legislation.gov.uk/ ukpga/Geo5/1-2/13/contents (accessed 13 March 2019).

Toronto Globe (1924), 'The senate as an issue', Toronto Globe, 22 December. 